Abstracta Iranicacta Iranica

Revue bibliographique pour le domaine irano-aryen

Volume 22 | 2001

Comptes rendus des publications de 1999

\title{
Tadjikistan. Chants des bardes. Genève, AIMP, 1999, texte de présentation et enregistrements.
}

\section{Rédaction}

\section{(2) OpenEdition \\ 1 Journals}

Édition électronique

URL : http://journals.openedition.org/abstractairanica/37368

DOI : 10.4000/abstractairanica.37368

ISSN : 1961-960X

\section{Éditeur :}

CNRS (UMR 7528 Mondes iraniens et indiens), Éditions de l'IFRI

\section{Édition imprimée}

Date de publication : 15 mai 2001

ISSN : 0240-8910

\section{Référence électronique}

Rédaction, «Tadjikistan. Chants des bardes. Genève, AIMP, 1999, texte de présentation et enregistrements. », Abstracta Iranica [En ligne], Volume 22 | 2001, document 656, mis en ligne le 17 février 2010, consulté le 13 octobre 2020. URL : http://journals.openedition.org/abstractairanica/ 37368 ; DOI : https://doi.org/10.4000/abstractairanica.37368

Ce document a été généré automatiquement le 13 octobre 2020.

Tous droits réservés 


\section{Tadjikistan. Chants des bardes. Genève, AIMP, 1999, texte de présentation et enregistrements.}

\section{Rédaction}

1 Ce $C D$ met en œuvre une poésie classique ou semi-classique, selon une tradition musicale très forte, qui est en voie de disparition ou de transformation actuellement. La plupart des bardes présents dans le recueil sont morts depuis l'enregistrement.

INDEX

Thèmes : 17.1.Musique

\section{AUTEURS}

RÉDACTION

Directeur de la revue et secrétariats (Paris et Téhéran) 